\title{
Sputum-to-serum hydrogen sulfide ratio in COPD
}

\author{
Junpei Saito, ${ }^{1,2,3}$ Alex J Mackay, ${ }^{4}$ Christos Rossios, ${ }^{1,2}$ David Gibeon, ${ }^{1,2}$ \\ Patricia Macedo, ${ }^{1,2}$ Rudy Sinharay, ${ }^{1,2}$ Pankaj K Bhavsar, ${ }^{1}$ Jadwiga A Wedzicha, ${ }^{3}$ \\ Kian Fan Chung ${ }^{1,2}$
}

- Additional material is published online only. To view please visit the journal online (http://dx.doi.org/10.1136/ thoraxjnl-2013-204868).

${ }^{1}$ Section of Experimental Studies, National Heart and Lung Institute, Imperial College London, London, UK ${ }^{2}$ NIHR Respiratory Biomedical Research Unit at the Royal Brompton NHS Foundation Trust and Imperial College London, London, UK ${ }^{3}$ Department of Pulmonary Medicine, Fukushima Medical University, Fukushima, Japan

${ }^{4}$ Centre for Respiratory Medicine, University College London Medical School, Royal Free Campus, London, UK

\section{Correspondence to}

Professor K F Chung, Experimental Studies, National Heart and Lung Institute, Imperial College London, Dovehouse St, London SW3 6LY, UK

f.chung@imperial.ac.uk

Received 26 November 2013 Revised 29 May 2014 Accepted 23 June 2014 Published Online First 17 July 2014
CrossMark

To cite: Saito J, Mackay AJ, Rossios C, et al. Thorax 2014;69:903-909.

\section{ABSTRACT}

Objectives Hydrogen sulfide $\left(\mathrm{H}_{2} \mathrm{~S}\right)$ is a gas produced by respiratory cells including smooth muscle cells and may play a role as a cellular gasotransmitter. We evaluated whether $\mathrm{H}_{2} \mathrm{~S}$ levels in serum or sputum could represent a new biomarker of COPD in a cross-sectional study.

Methods $\mathrm{H}_{2} \mathrm{~S}$ levels in sputum and serum samples were measured using a sulfide-sensitive electrode in 64 patients with stable COPD (S-COPD), 29 COPD subjects during acute exacerbation (AE-COPD), 14 healthy smokers and 21 healthy non-smokers.

Results Sputum $\mathrm{H}_{2} \mathrm{~S}$ levels in AE-COPD subjects were higher than those in S-COPD, healthy smoking and nonsmoking subjects $(p<0.001)$, but serum $\mathrm{H}_{2} \mathrm{~S}$ levels in $\mathrm{AE}$ COPD were lower than those in S-COPD $(p<0.001)$. Thus, the sputum-to-serum ratio of $\mathrm{H}_{2} \mathrm{~S}\left(\mathrm{H}_{2} \mathrm{~S}\right.$ ratio) in AE-COPD subjects were higher than those in stable COPD, healthy smoking and non-smoking subjects $(p<0.001)$. In 14 COPD subjects whose $\mathrm{H}_{2} \mathrm{~S}$ ratios were measured during and after an exacerbation, the mean ratio was increased during exacerbation $(p<0.05)$. $\mathrm{H}_{2} \mathrm{~S}$ ratio was positively correlated with St. George's Respiratory Questionnaire score, sputum neutrophils and IL-6 and IL-8 levels in sputum and serum $(p<0.01)$ but inversely correlated with sputum macrophages (\%), FEV $1 \%$ predicted and $\mathrm{FEV}_{1} / \mathrm{FVC}$ $(p<0.01)$. The cut-off level of $\mathrm{H}_{2} \mathrm{~S}$ ratio to indicate an exacerbation was $\geq 0.44$ (sensitivity of $93.1 \%$ and specificity of $84.5 \%$ ).

Conclusions The ratio of sputum-to-serum levels of $\mathrm{H}_{2} \mathrm{~S}$ may provide a useful marker of COPD indicative of obstructive neutrophilic inflammation and of potential ongoing exacerbation.

\section{INTRODUCTION}

COPD is one of the major causes of morbidity and mortality, likely to become the third global cause by 2020. ${ }^{1}$ COPD is characterised by persistent progressive airflow limitation and chronic pulmonary inflammation. ${ }^{2}$ Exacerbations of COPD characterised by worsening of respiratory symptoms are commonly observed in more severe disease and have been linked to lung function decline, cardiovascular events and death, ${ }^{3} 4$ and with increased pulmonary and extrapulmonary inflammation. ${ }^{5-8}$ Systemic inflammation may be a key link between COPD and comorbidities, possibly resulting from a spillover from the lung into the systemic circulation. ${ }^{9} 10$

Hydrogen sulfide $\left(\mathrm{H}_{2} \mathrm{~S}\right)$, a gas with a typical malodorous smell, is produced by many cell types in the lungs including pulmonary arterial and airway
Key messages

What is the key question?

- We evaluated whether $\mathrm{H}_{2} \mathrm{~S}$ levels in serum or sputum could represent a new biomarker of COPD.

\section{What is the bottom line?}

- We found that the ratio of sputum-to-serum levels of $\mathrm{H}_{2} \mathrm{~S}$ may provide a useful marker of COPD indicative of obstructive neutrophilic inflammation and of potential future risk of exacerbation.

\section{Why read on?}

- Concomitant measurement of $\mathrm{H}_{2} \mathrm{~S}$ in sputum and in serum represents a novel promising biomarker of COPD.

smooth muscle cells, primary fibroblasts and endothelial cells ${ }^{11-13}$ through the action of three enzymes, namely, cystathionine- $\gamma$-lyase (CSE), cystathionine- $\beta$ synthase (CBS) and 3-mercaptopyruvate sulfur transferase. ${ }^{14} \mathrm{H}_{2} \mathrm{~S}$ is the third gasotransmitter along with nitric oxide (NO) and carbon monoxide (CO), with vasodilator and neurotransmitter properties. ${ }^{15} \mathrm{H}_{2} \mathrm{~S}$ may also be involved in anti-inflammatory processes and has been reported to reduce cigarette smoke-induced lung inflammation in mice. ${ }^{16}$ It also has reducing properties and can scavenge various oxidising and nitrative species such as superoxide and peroxynitrite. ${ }^{17}$ In vivo, $\mathrm{H}_{2} \mathrm{~S}$ prevented endothelial disruption and lung vascular leakage induced by particulate air pollution through scavenging reactive oxygen species. ${ }^{18}$

$\mathrm{H}_{2} \mathrm{~S}$ levels in the lung as well as in serum have been assayed in asthma and COPD. In COPD, higher levels of serum $\mathrm{H}_{2} \mathrm{~S}$ have been reported compared with healthy non-smokers (HNS), with lower levels during an acute exacerbation. ${ }^{19}$ In asthma, $\mathrm{H}_{2} \mathrm{~S}$ levels in both sputum and serum were strongly correlated with obstructive neutrophilic airway inflammation. ${ }^{20}$ Therefore, $\mathrm{H}_{2} \mathrm{~S}$ could be considered as a potential biomarker of chronic airway diseases. ${ }^{21}$ The aims of our study were (i) to measure sputum and serum $\mathrm{H}_{2} \mathrm{~S}$ levels in patients with COPD during a stable period and during an exacerbation, and (ii) to examine their relationships to key markers of disease activity and neutrophilic inflammation. In addition, we evaluated whether sputum and serum levels of $\mathrm{H}_{2} \mathrm{~S}$ could indicate an ongoing exacerbation. 


\section{METHODS}

\section{Subjects}

In total, 64 subjects with stable COPD (S-COPD) and 29 subjects with acute exacerbation of COPD (AE-COPD) were recruited from the clinics of the Royal Brompton and Royal Free Hospitals in London. Fourteen healthy smokers (HS) and 21 HNS were recruited from advertisement (table 1). The diagnosis of COPD was made according to the Global Initiative for Chronic Obstructive Lung Disease (GOLD) guidelines. ${ }^{22}$ Briefly, COPD subjects had a history of chronic respiratory symptoms (ie, dyspnoea, coughing, sputum or both), a smoking history of $>10$ pack-years and a postbronchodilator $\mathrm{FEV}_{1} / \mathrm{FVC}$ ratio $<70 \%$. COPD subjects were categorised as severe (stages III and IV) or non-severe (stages I and II). Subjects with concomitant respiratory diseases other than COPD were excluded. HS $(\geq 10$ pack-years) and HNS ( $\leq 5$ pack-years) had normal lung function, no bronchial hyperresponsiveness and no history of pulmonary disease. All participants gave informed consent to a protocol approved by the Ethics Committee.

\section{COPD exacerbation}

An acute exacerbation was defined as new or increased respiratory symptoms for two or more consecutive days, with at least one major symptom (dyspnoea and sputum production) with either another major or minor symptom (wheeze, cold, sore throat and cough). All exacerbation visits occurred within 7 days after its onset. A stable state was defined as having no symptoms related to exacerbation for the preceding 6 weeks. ${ }^{23}$

\section{Study design}

This was a cross-sectional observational study. Health status was assessed with the Medical Research Council (MRC) dyspnoea scale $^{24}$ and the St. George's Respiratory Questionnaire (SGRQ). ${ }^{25}$ Lung function tests, 6 minute walk test (6MWT) and sputum and peripheral blood samplings were performed. In 14 COPD subjects, $\mathrm{H}_{2} \mathrm{~S}$ levels in sputum and serum were obtained during an exacerbation and during the stable state.

\section{Sputum induction and processing}

Sputum induction was performed with inhaled nebulised $4.5 \%$ $\mathrm{NaCl}$ solution. ${ }^{26}$ Sputum plugs were harvested and processed with $0.1 \%$ dithiothreitol (DTT) and sulfide antioxidant buffer added to sputum supernatant and stored at $-80{ }^{\circ} \mathrm{C}$. Cytospins were prepared for differential cell counts.

Table 1 Characteristics, lung function and treatment of cohorts

\begin{tabular}{|c|c|c|c|c|}
\hline & Healthy non-smoker $(n=21)$ & Healthy smoker $(n=14)$ & Stable COPD $(n=64)$ & COPD with exacerbation $(n=29)$ \\
\hline Age (years) & $49.2(9.24)$ & $54.4(7.31)$ & $69.1(8.56)^{*}+$ & $74.7(9.06)^{*}+$ \\
\hline Sex (male/female) & $13 / 8$ & $6 / 8$ & $33 / 31$ & $18 / 11$ \\
\hline Height $(\mathrm{cm})$ & $168.3(7.80)$ & $165.8(7.96)$ & $166.7(8.32)$ & $167.4(9.06)$ \\
\hline Weight (kg) & $67.7(17.6)$ & $66.6(14.0)$ & $72.7(14.2)$ & $70.8(13.0)$ \\
\hline BMI & $23.8(5.10)$ & $24.2(4.46)$ & $26.1(4.41)$ & $25.2(4.02)$ \\
\hline Smoking (pack-years), median (IQR) & N/A & $23.0(19.3-31.8)$ & $39.8(27.5-55.0)$ & $37.4(19.7-51.3)$ \\
\hline GOLD stage (I/II/III/IV)) & N/A & $\mathrm{N} / \mathrm{A}$ & $5 / 36 / 19 / 4$ & $2 / 14 / 12 / 1$ \\
\hline MRC score (1-5) & N/A & $\mathrm{N} / \mathrm{A}$ & $2.57(0.98)$ & $3.46(1.04)^{9}$ \\
\hline Baseline SPO2 (\%) & $97.4(1.51)$ & $97.2(1.14)$ & $94.8(2.26)^{*}+$ & $94.8(2.48)^{*}+$ \\
\hline \multicolumn{5}{|l|}{ SGRQ score } \\
\hline Symptom score & $3.91(6.22)$ & $25.8(20.1)^{*}$ & $58.6(22.3)^{\star \dagger}$ & N/D \\
\hline Activity score & $1.97(3.70)$ & $23.4(22.3)^{*}$ & $61.1(24.9)^{* \dagger}$ & $\mathrm{N} / \mathrm{D}$ \\
\hline Impact score & $0.26(1.00)$ & $4.91(7.49)$ & $28.9(16.9)^{* \dagger}$ & N/D \\
\hline Total score & $1.30(1.26)$ & $13.6(12.9)$ & $43.3(19.1)^{*}+$ & $N / D$ \\
\hline 6 minute walk distance(m) & $594(36.5)$ & $497(64.0)$ & $414(82.1)^{*}+$ & $\mathrm{N} / \mathrm{D}$ \\
\hline $\mathrm{FEV}_{1}$ (\%pred) & $99.8(12.1)$ & $89.3(11.4)$ & $55.6(16.6)^{*}+$ & $55.1(17.4)^{*}+$ \\
\hline FVC (\%pred) & $103.0(11.2)$ & $98.3(13.2)$ & $86.6(20.2)^{*}+$ & $89.3(21.9)^{*}$ \\
\hline $\mathrm{FEV}_{1} / \mathrm{FVC}(\%)$ & $82.0(5.42)$ & $76.4(5.16)$ & $52.4(12.7)^{*}+$ & $49.7(9.30)^{*}+$ \\
\hline $\mathrm{TL}_{\mathrm{CO}}(\%)$ & $88.0(16.8)$ & $75.5(15.9)$ & $62.4(17.6)^{*}$ & $\mathrm{~N} / \mathrm{D}$ \\
\hline $\mathrm{K}_{\mathrm{CO}}(\%)$ & $91.5(12.2)$ & $82.3(14.8)$ & $73.5(20.1)^{*}$ & $\mathrm{~N} / \mathrm{D}$ \\
\hline WBC, median (IQR) & $5.60(5.00-7.70)$ & $6.80(5.50-8.65)$ & $7.10(6.00-9.24)$ & $7.95(6.87-9.63)^{*}$ \\
\hline Neutrophil, median (IQR) & $3.40(2.80-4.10)$ & $4.10(2.90-5.10)$ & $7.10(6.00-9.24)^{*}$ & $7.95(6.87-9.63)^{*}+9$ \\
\hline CRP, median (IQR) & $0.50(0.50-1.00)$ & $2.00(0.50-5.50)$ & $3.00(2.00-10.0)$ & $13.5(6.25-28.5)^{* \dagger ๆ}$ \\
\hline Sputum macrophages (\%), median (IQR) & $85.8(64.7-87.8)$ & $45.8(19.9-58.9)^{*}$ & $30.6(17.5-49.0)^{*}$ & $18.7(8.50-24.5)^{*}+$ \\
\hline Sputum neutrophils (\%), median (IQR) & $12.3(6.67-33.5)$ & $52.5(37.9-79.2)^{*}$ & $63.0(43.4-79.0)^{*}$ & $80.5(72.8-91.3)^{*}+$ \\
\hline Sputum eosinophils (\%), median (IQR) & $0.70(0.22-1.00)$ & $0.68(0.21-1.00)$ & $1.44(0.50-2.52)$ & $0(0-1.25)$ \\
\hline \multicolumn{5}{|l|}{ Maintenance therapy } \\
\hline SABA or SAMA, $n(\%)$ & $\mathrm{N} / \mathrm{A}$ & N/A & $13(20.3)$ & $7(24.1)$ \\
\hline LABA or LAMA, n (\%) & N/A & N/A & $1(1.6)$ & $0(0)$ \\
\hline ICS+(LABA or LAMA), $n(\%)$ & N/A & $\mathrm{N} / \mathrm{A}$ & $16(25)$ & $8(27.6)$ \\
\hline ICS+LABA+LAMA, n (\%) & N/A & N/A & $34(53.1)$ & $14(48.3)$ \\
\hline
\end{tabular}

Data are presented as mean (SD) unless otherwise indicated, ${ }^{*} p<0.05$ versus healthy non-smoker, ${ }^{\dagger} p<0.05$ versus healthy smoker, ${ }^{7} p<0.05$ versus stable COPD.

$\mathrm{BMI}$, body mass index; CRP, C-reactive protein; GOLD, Global Initiative for Chronic Obstructive Lung Disease; ICS, inhaled corticosteroid; $\mathrm{K}_{\mathrm{CO}}$, carbon monoxide transfer coefficient; LABA, long-acting $\beta$-agonist; LAMA, long-acting muscarinic antagonist; MRC, Medical Research Council; N/A, not applicable; N/D, not done; SABA, short-acting $\beta 2$-agonist; SAMA, short-acting muscarinic antagonist; SGRQ, St. George's Respiratory Questionnaire; $\mathrm{TL}_{\mathrm{co}}$, transfer factor of the lung for carbon monoxide; WBC, white blood cell. 


\section{Measurement of $\mathrm{H}_{2} \mathrm{~S}$}

$\mathrm{H}_{2} \mathrm{~S}$ concentrations in serum and sputum were measured using a sulfide-sensitive electrode (Model 9616; Orion Research; Beverly, Massachusetts, USA). Briefly, standard solutions were made using $0.1 \%$ DTT plus phosphate-buffered saline or distilled water for sputum and serum $\mathrm{H}_{2} \mathrm{~S}$ measurement respectively in order to minimise any effect of DTT. The electrode was placed into the standard solutions for measurement of $\mathrm{H}_{2} \mathrm{~S}$ levels and the calibration standard curve constructed. Validation of $\mathrm{H}_{2} \mathrm{~S}$ measurements including accuracy, reproducibility and storage effects of samples has been reported. ${ }^{20}$

\section{Measurement of IL- 6 and IL-8}

IL- 6 and IL- 8 in serum and sputum supernatants were measured using a commercially available sandwich ELISA kit (R\&D Systems, Minneapolis, Minnesota, USA).

\section{Statistical analysis}

The main outcome predictor was $\mathrm{H}_{2} \mathrm{~S}$ levels in sputum and serum, or the ratio of sputum to serum $\mathrm{H}_{2} \mathrm{~S}$ levels. At least 14 subjects were needed per group for a $70 \%$ power to detect a $20 \%$ difference in $\mathrm{H}_{2} \mathrm{~S}$ levels between each group with a twosided $\alpha$ of 0.05 .

Data are shown as mean and SD for normally distributed variables, and median and IQR for non-normally distributed variables. Comparisons of continuous variables between groups were made using Kruskall-Wallis and Mann-Whitney U test with Bonferroni correction. $\chi^{2}$ or Fisher's exact test was used for the comparison of categorical data. Differences of paired samples in the same subjects were analysed by Wilcoxon matched-pairs signed rank test. Linear regression modelling was used to evaluate the simple and joint associations of $\mathrm{H}_{2} \mathrm{~S}$ levels in sputum and serum with parameters that were relevant to COPD, adjusting for age, sex, height, weight and smoking status. Then, multiple linear regression analysis, using a forward stepwise selection, was conducted to determine the independent association of $\mathrm{H}_{2} \mathrm{~S}$ levels with parameters with $\mathrm{p}$ value $<0.05$ obtained from regression modelling. Finally, receiver operating characteristic (ROC) curve was constructed to determine the predictive value of the sputum-to-serum $\mathrm{H}_{2} \mathrm{~S}$ ratio for an exacerbation. A two-tailed $\mathrm{p}$ value $<0.05$ was considered significant.

\section{RESULTS}

\section{Characteristics of participants}

Forty-one (64.0\%) in S-COPD group and 16 (55.2\%) in AE-COPD group had mild-to-moderate COPD. $\mathrm{SpO}_{2}$ at rest, $\mathrm{FEV}_{1}, \mathrm{FVC}, \mathrm{FEV}_{1} / \mathrm{FVC}$ ratio and sputum macrophages in COPD subjects were lower than in healthy subjects $(p<0.05)$. The 6MWT distance in S-COPD subjects was also shorter $(\mathrm{p}<0.05)$. Total SGRQ score and neutrophils in blood and sputum in S-COPD and AE-COPD subjects were higher than those of HNS $(p<0.05)$.

\section{$\mathrm{H}_{2} \mathrm{~S}$ levels in sputum and serum}

$\mathrm{H}_{2} \mathrm{~S}$ levels in induced sputum from S-COPD $(31.9 \pm 15.0 \mu \mathrm{M})$ were higher than those from HNS $(12.1 \pm 6.64 \mu \mathrm{M}$; $\mathrm{p}<0.001)$. In addition, sputum $\mathrm{H}_{2} \mathrm{~S}$ levels in AE-COPD subjects $(50.4 \pm 24.4 \mu \mathrm{M})$ were much higher than those from S-COPD, HS and HNS subjects $(31.9 \pm 15.0,12.1 \pm 6.64$, $19.7 \pm 7.98 \mu \mathrm{M}$, respectively; $\mathrm{p}<0.001$ ) (figure $1 \mathrm{~A}$ ). The concomitant serum $\mathrm{H}_{2} \mathrm{~S}$ levels in S-COPD $(148.9 \pm 77.6 \mu \mathrm{M})$ were also higher than those from HNS and HS (91.0 \pm 62.2 , $90.6 \pm 52.7 \mu \mathrm{M}$, respectively; $\mathrm{p}<0.05)$. However, unlike the sputum $\mathrm{H}_{2} \mathrm{~S}$ levels, the concomitant serum $\mathrm{H}_{2} \mathrm{~S}$ levels in AE-COPD $(48.9 \pm 25.5 \mu \mathrm{M})$ were much lower compared with those in S-COPD (figure 1B). There was no difference in $\mathrm{H}_{2} \mathrm{~S}$ levels between non-severe and severe COPD subjects during both stable and exacerbated states (see online supplementary figure E1).

\section{Relationships between $\mathrm{H}_{2} \mathrm{~S}$ levels and COPD parameters}

Table 2 shows the correlations between sputum $\mathrm{H}_{2} \mathrm{~S}$, serum $\mathrm{H}_{2} \mathrm{~S}$ levels and clinically relevant parameters in S-COPD. Both sputum and serum $\mathrm{H}_{2} \mathrm{~S}$ levels positively correlated with MRC scores, total SGRQ scores, sputum neutrophils and serum IL-8 levels $(\mathrm{p}<0.01)$. Sputum $\mathrm{H}_{2} \mathrm{~S}$ levels, but not serum $\mathrm{H}_{2} \mathrm{~S}$ levels, showed positive correlations with sputum IL-8 and sputum IL-6 levels $(\mathrm{p}<0.01)$. In addition, there were negative correlations between sputum as well as serum $\mathrm{H}_{2} \mathrm{~S}$ levels and $\mathrm{SpO}_{2}$ at rest, 6MWT distance, $\mathrm{FEV}_{1} \%$ predicted, $\mathrm{FEV}_{1} / \mathrm{FVC}$, and sputum macrophages $(\mathrm{p}<0.01)$. Sputum $\mathrm{H}_{2} \mathrm{~S}$ levels, but not serum $\mathrm{H}_{2} \mathrm{~S}$, were negatively correlated to transfer factor of the lung for carbon monoxide $\left(\mathrm{TL}_{\mathrm{CO}}\right)$ and carbon monoxide diffusing capacity adjusted for alveolar volume $\left(\mathrm{K}_{\mathrm{CO}}\right) \quad(\mathrm{p}<0.01)$. When adjusted for the potential confounding factors (age, sex, height, weight and smoking status), sputum $\mathrm{H}_{2} \mathrm{~S}$ levels were still correlated with $6 \mathrm{MWT}$ distance, $\mathrm{FEV}_{1} \%$ predicted, $\mathrm{FEV}_{1} / \mathrm{FVC}$ ratio, $\mathrm{TL}_{\mathrm{CO}}$, sputum macrophages (\%), sputum neutrophils (\%) and sputum IL-8 levels. Similarly, serum $\mathrm{H}_{2} \mathrm{~S}$ levels were significantly correlated with $\mathrm{FEV}_{1} \%$ predicted and $\mathrm{FEV}_{1} / \mathrm{FVC}$ ratio. For AE-COPD subjects, there was no significant correlation between sputum $\mathrm{H}_{2} \mathrm{~S}$, serum $\mathrm{H}_{2} \mathrm{~S}$ levels and other COPD-related parameters (data not shown).

Using multiple linear regression analysis to determine the independent association with sputum and serum $\mathrm{H}_{2} \mathrm{~S}$ (table 3 ), sputum $\mathrm{H}_{2} \mathrm{~S}$ was associated with increased sputum neutrophil (\%) and sputum IL-8 levels, and decreased $\mathrm{FEV}_{1}$ (\% predicted) $(\mathrm{p} \leq 0.05)$, and serum $\mathrm{H}_{2} \mathrm{~S}$ was associated with decreased $\mathrm{FEV}_{1}$ (\% predicted) $(\mathrm{p}=0.03)$. Sputum and serum $\mathrm{H}_{2} \mathrm{~S}$ were not influenced by age, sex, height, weight and smoking status.

\section{Sputum-to-serum $\mathrm{H}_{2} \mathrm{~S}$ ratio}

We examined the ratio of sputum-to-serum levels, the ${ }^{\prime} \mathrm{H}_{2} \mathrm{~S}$ ratio'. $\mathrm{H}_{2} \mathrm{~S}$ ratio in AE-COPD (mean 1.42; 95\% CI 0.89 to
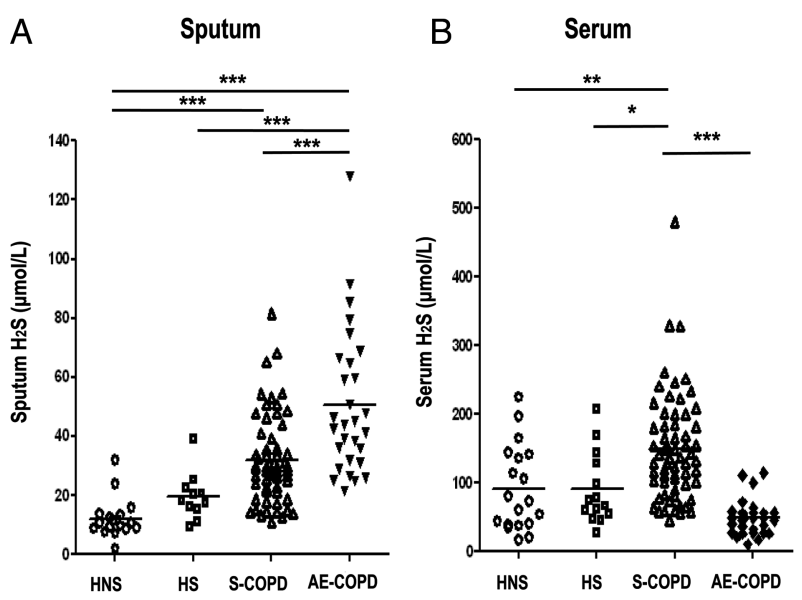

Figure $1 \mathrm{H}_{2} \mathrm{~S}$ levels in sputum (A) and serum (B) from stable COPD subjects (S-COPD: $\triangle$ ), COPD subjects with acute exacerbation (AE-COPD: $\boldsymbol{\nabla})$, healthy smoking (HS: $\square$ ), and non-smoking subjects (HNS: $\bigcirc$ ). Horizontal bars indicate mean. ${ }^{* * *} p \leq 0.001$. 
Table 2 Correlation analysis between $\mathrm{H}_{2} \mathrm{~S}$ in sputum and serum and other parameters related to COPD

\begin{tabular}{|c|c|c|c|c|}
\hline \multirow[b]{2}{*}{ Variables } & \multicolumn{2}{|l|}{ Sputum $\mathrm{H}_{2} \mathrm{~S}$} & \multicolumn{2}{|l|}{ Serum $\mathrm{H}_{2} \mathrm{~S}$} \\
\hline & $\begin{array}{l}\text { Crude } \\
\boldsymbol{\beta} \text { value }(95 \% \mathrm{Cl})\end{array}$ & $\begin{array}{l}\text { Adjustedt } \\
\text { 及 value }(95 \% \mathrm{Cl})\end{array}$ & $\begin{array}{l}\text { Crude } \\
\beta \text { value }(95 \% \mathrm{Cl})\end{array}$ & $\begin{array}{l}\text { Adjustedt } \\
\text { B value }(95 \% \mathrm{Cl})\end{array}$ \\
\hline MRC score & $6.006(3.258 \text { to } 8.754)^{* * *}$ & - & $14.83(0.781 \text { to } 28.87)^{*}$ & - \\
\hline SGRQ score & $0.200(0.066 \text { to } 0.333)^{* *}$ & - & $0.685(0.005 \text { to } 1.366)^{*}$ & - \\
\hline Baseline $\mathrm{SpO}_{2}(\%)$ & $-1.860(-3.386 \text { to }-0.335)^{*}$ & - & $-9.415(-15.73 \text { to }-3.098)^{* *}$ & - \\
\hline $6 \mathrm{MWD}(\mathrm{m})$ & $-0.084(-0.122 \text { to }-0.045)^{* * *}$ & $-0.065(-0.117 \text { to }-0.013)^{*}$ & $-0.218(-0.405 \text { to }-0.031)^{*}$ & - \\
\hline FEV1\%predicted (\%) & $-0.337(-0.452 \text { to }-0.222)^{* * *}$ & $-0.272(-0.430 \text { to }-0.114)^{* *}$ & $-1.161(-1.749 \text { to }-0.573)^{* * *}$ & $-1.167(-1.989 \text { to }-0.346)^{* *}$ \\
\hline FEV1/FVC (\%) & $-0.441(-0.612 \text { to }-0.270)^{* * *}$ & $-0.341(-0.575 \text { to }-0.106)^{* *}$ & $-1.426(-2.291 \text { to }-0.560)^{* *}$ & $-1.271(-2.522 \text { to }-0.020)^{*}$ \\
\hline $\mathrm{TL}_{\mathrm{CO}}(\%)$ & $-0.333(-0.524 \text { to }-0.143)^{* * *}$ & $-0.261(-0.491 \text { to }-0.031)^{* *}$ & $-0.621(-1.661$ to 0.420$)$ & - \\
\hline $\mathrm{K}_{\mathrm{CO}}(\%)$ & $-0.275(-0.460 \text { to }-0.099)^{* *}$ & - & $-0.594(-1.561$ to 0.412$)$ & - \\
\hline Sputum macrophages (\%) & $-0.364(-0.465 \text { to }-0.263)^{* * *}$ & $-0.331(-0.446 \text { to }-0.216)^{* * *}$ & $-0.864(-1.508 \text { to }-0.221)^{* *}$ & - \\
\hline Sputum neutrophils (\%) & $0.353(0.251 \text { to } 0.454)^{* * *}$ & $0.309(0.193 \text { to } 0.424)^{* * *}$ & $0.868(0.223 \text { to } 1.512)^{* *}$ & - \\
\hline Serum IL8 (pg/mL) & $0.409(0.045 \text { to } 0.773)^{*}$ & - & $1.768(0.184 \text { to } 3.352)^{*}$ & - \\
\hline Serum IL6 (pg/mL) & $0.912(-0.923$ to 2.748$)$ & - & $10.62(2.522 \text { to } 18.72)^{*}$ & - \\
\hline Sputum IL8 (pg/mL) & $0.017(0.009 \text { to } 0.024)^{* * *}$ & $0.013(0.005 \text { to } 0.022)^{* *}$ & $0.012(-0.036$ to 0.059$)$ & - \\
\hline Sputum IL6 (pg/mL) & $0.038(0.010 \text { to } 0.066)^{* *}$ & - & $-0.075(-0.284$ to 0.134$)$ & - \\
\hline
\end{tabular}

1.96) was higher than that in S-COPD subjects (mean 0.27; $95 \%$ CI 0.22 to 0.32 ), HNS (mean $0.20 ; 95 \%$ CI 0.11 to 0.28 ) and HS (mean 0.24 ; 95\% CI 0.17 to 0.31 ) ( $\mathrm{p}<0.001)$ subjects (figure 2A). For further confirmation of this difference, paired samples of sputum and serum during exacerbation as well as stable state from 14 COPD subjects were obtained. $\mathrm{H}_{2} \mathrm{~S}$ ratio during exacerbation (mean 1.54;95\% CI 0.58 to 2.49 ) was increased compared with that during stable state in all 14 participants (mean 0.28 , 95\% CI 0.19 to 0.36 ) (figure 2B) $(\mathrm{p}<0.01)$.

\section{Sputum-to-serum IL-8 and IL-6 ratios}

We determined whether the sputum-to-serum ratios of the levels of IL- 6 and IL-8 could also be altered during exacerbations. IL-8 ratio in AE-COPD (mean 54.8; 95\% CI 46.3 to 63.4 ) was lower than that in HS $(p<0.01)$, but was not different from $\mathrm{S}$-COPD and HNS (figure 3A). There was no significant difference in IL-6 ratio between the groups (figure 3B). Both serum and sputum IL- 6 levels were increased in AE-COPD compared with S-COPD, while only serum IL-8 was increased (see online supplementary figure E2).

Table 3 Independent parameters associated with $\mathrm{H}_{2} \mathrm{~S}$ in sputum and serum using multiple linear regression analysis*

\begin{tabular}{|c|c|c|c|c|}
\hline Risk factor & $\boldsymbol{\beta}$ value & $95 \% \mathrm{Cl}$ & p Value & $\mathbf{R}^{2}$ \\
\hline Sputum $\mathrm{H}_{2} \mathrm{~S}$ & & & & 0.563 \\
\hline $\mathrm{FEV}_{1} \%$ predicted & -0.499 & -0.900 to -0.099 & 0.016 & \\
\hline Sputum neutrophils & 0.271 & 0.066 to 0.476 & 0.011 & \\
\hline Sputum IL-8 & 0.016 & 0.004 to 0.028 & 0.012 & \\
\hline Serum $\mathrm{H}_{2} \mathrm{~S}$ & & & & 0.263 \\
\hline $\mathrm{FEV}_{1} \%$ predicted & -0.621 & -1.179 to -0.063 & 0.029 & \\
\hline
\end{tabular}

$\mathrm{H}_{2} \mathrm{~S}$ ratio, bacterial sputum cultures and onset of exacerbations

$\mathrm{H}_{2} \mathrm{~S}$ ratio in AE-COPD with negative bacterial sputum cultures (mean 2.33 ; 95\% CI 0.65 to 4.01 ) was higher than that in AE-COPD with positive sputum cultures (mean 1.03; 95\% CI 0.52 to 1.54$)(\mathrm{p}<0.05), \mathrm{S}$-COPD with negative (mean 0.28 ; 95\% CI 0.21 to 0.36 ) and S-COPD with positive bacteria (mean 0.25 ; $95 \%$ CI 0.14 to 0.36$)(\mathrm{p}<0.001)$. There was no difference in $\mathrm{H}_{2} \mathrm{~S}$ ratio between S-COPD with and without bacteria (figure 4A).

There was a negative correlation between $\mathrm{H}_{2} \mathrm{~S}$ ratio and the time interval from exacerbation onset to a hospital visit, that is, the greater the $\mathrm{H}_{2} \mathrm{~S}$ ratio, the shorter the time of presentation to hospital $(r=-0.45 ; \mathrm{p}=0.02)$ (figure 4B).
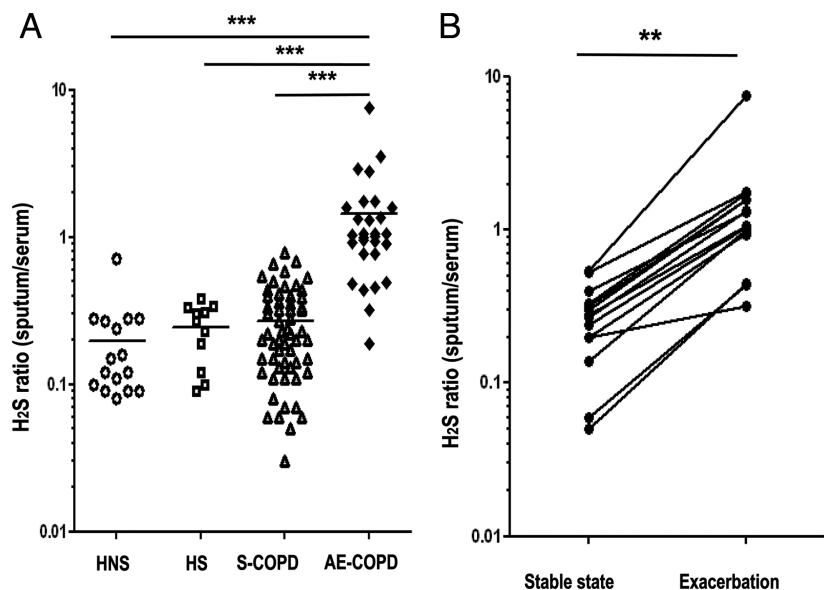

Figure 2 (A) $\mathrm{H}_{2} \mathrm{~S}$ sputum-to-serum ratio in stable COPD subjects (S-COPD: $\triangle$ ), COPD subjects with acute exacerbation (AE-COPD: $\mathbf{\nabla})$, healthy smoking (HS: $\square$ ) and non-smoking subjects (HNS: $\bigcirc$ ). Horizontal bars indicate mean. ${ }^{* * *} \mathrm{p} \leq 0.001$. (B) Difference in $\mathrm{H}_{2} \mathrm{~S}$ sputum-to-serum ratio between stable and exacerbation state. At acute exacerbation, $\mathrm{H}_{2} \mathrm{~S}$ ratio increased in comparison with that in stable state. ${ }^{* *} \mathrm{p} \leq 0.01$. 

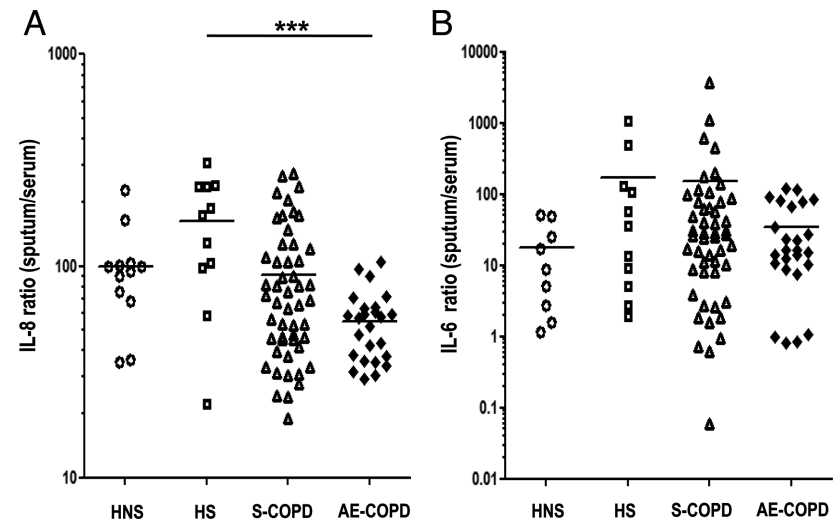

Figure 3 IL-8 sputum-to-serum ratio (A) and IL-6 sputum-to-serum ratio (B) from stable COPD subjects (S-COPD: $\Delta$ ), COPD subjects with acute exacerbation (AE-COPD: $\mathbf{\gamma})$, healthy smoking (HS: $\square$ ) and non-smoking subjects (HNS:O). Horizontal bars indicate mean. $* * * \mathrm{p} \leq 0.001$.

\section{$\mathrm{H}_{2} \mathrm{~S}$ ratio as indicative of an exacerbation}

ROC curves were constructed to determine the cut-off level of $\mathrm{H}_{2} \mathrm{~S}$ ratio for indicating an acute exacerbation from stable COPD (figure 5). The optimal cut-off level of $\mathrm{H}_{2} \mathrm{~S}$ ratio for indicating an exacerbation was $\geq 0.44$ (area under the curve; 0.946 , sensitivity of $93.1 \%$ and specificity of $84.5 \%, \mathrm{p}<0.001)$.

\section{DISCUSSION}

In patients with COPD, sputum $\mathrm{H}_{2} \mathrm{~S}$ levels were elevated in S-COPD and AE-COPD compared with healthy smoking and non-smoking subjects; however, serum levels were higher in stable COPD but not during an acute exacerbation when compared with serum levels in healthy subjects. Chronic cigarette smoking itself did not influence serum or sputum levels. Sputum $\mathrm{H}_{2} \mathrm{~S}$ levels increased and serum $\mathrm{H}_{2} \mathrm{~S}$ levels dropped during acute exacerbations of COPD, as confirmed in patients where concomitant sputum and serum levels were measured at baseline and during an exacerbation. Both sputum and serum $\mathrm{H}_{2} \mathrm{~S}$ levels correlated inversely with the degree of airflow obstruction,
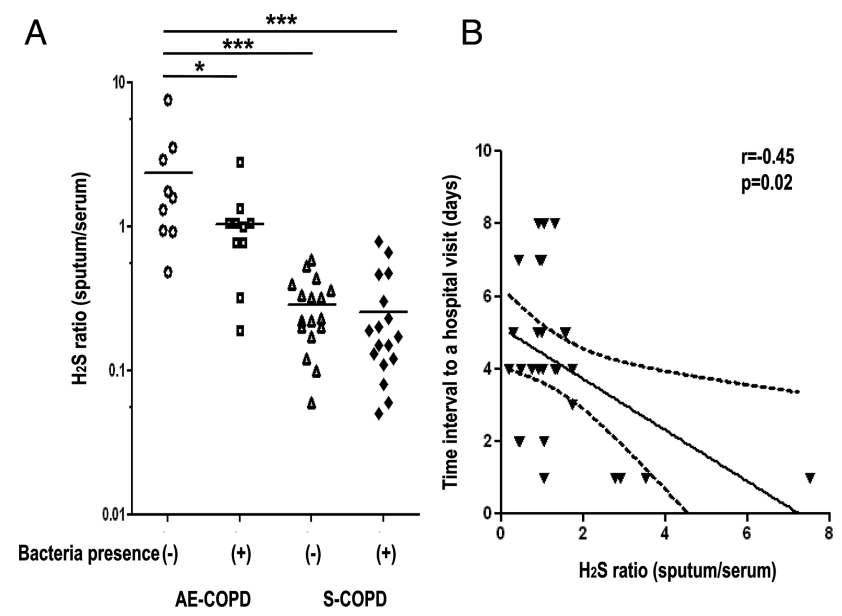

Figure 4 (A) $\mathrm{H}_{2} \mathrm{~S}$ sputum-to-serum ratio in AE-COPD and S-COPD with and without bacterial presence; $A E-C O P D$ without bacteria $(O)$, AE-COPD with bacteria $(\square)$, S-COPD without bacteria $(\Delta)$ and S-COPD with bacteria ( ). Horizontal bars indicate mean. (B) Relationship between $\mathrm{H}_{2} \mathrm{~S}$ ratio and the time interval from exacerbation onset to a hospital visit.

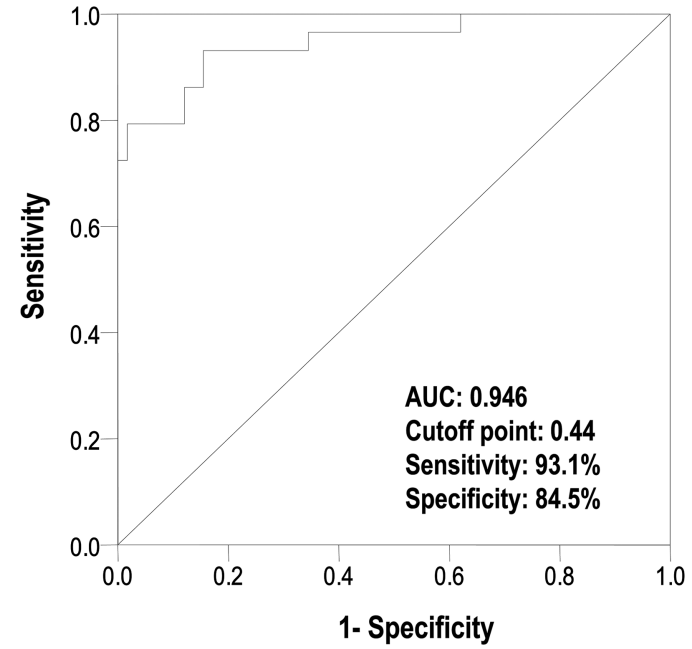

Figure 5 Receiver operator characteristics curve for $\mathrm{H}_{2} \mathrm{~S}$ sputum-to-serum ratio to predict the future risks of acute exacerbation.

suggesting that $\mathrm{H}_{2} \mathrm{~S}$ levels are closely related to physiological characteristics of COPD. There were positive relationships between sputum neutrophils (\%), serum IL-8 and $\mathrm{H}_{2} \mathrm{~S}$ levels in sputum and serum, indicating that $\mathrm{H}_{2} \mathrm{~S}$ levels may reflect neutrophilic airway inflammation. Furthermore, $\mathrm{H}_{2} \mathrm{~S}$ levels in sputum and serum were associated with $\mathrm{SpO}_{2}$ at rest, 6MWT distance, MRC score and SGRQ scores, indicating that $\mathrm{H}_{2} \mathrm{~S}$ may also be a marker of the degree of physical and quality-of-life impairment.

This is the first study to examine the levels of $\mathrm{H}_{2} \mathrm{~S}$ in sputum and serum during the stable and acute exacerbation phases of COPD. Previous studies have reported serum $\mathrm{H}_{2} \mathrm{~S}$ levels in COPD and during chest infections ${ }^{19}{ }^{27}$ and in agreement with our results, serum $\mathrm{H}_{2} \mathrm{~S}$ levels in patients with S-COPD were found to be higher than those in HNS, with lower levels in AE-COPD. ${ }^{19}$ Interestingly, the changes in sputum and serum $\mathrm{H}_{2} \mathrm{~S}$ levels between stable and exacerbation were entirely opposite with an increase in sputum $\mathrm{H}_{2} \mathrm{~S}$ levels and concomitant decrease in serum $\mathrm{H}_{2} \mathrm{~S}$ levels during acute exacerbation. Thus, the sputum-to-serum $\mathrm{H}_{2} \mathrm{~S}$ ratio increased sixfold during an exacerbation and a ratio $>0.44$ was indicative of an exacerbation. By comparison, the sputum-to-serum IL-6 and IL-8 ratios did not differentiate stable COPD and COPD during an exacerbation from non-smoking and smoking healthy subjects. This lack of differentiation is explained by the fact that serum IL-6 and IL- 8 levels increased during an exacerbation in contrast to the reduction in serum $\mathrm{H}_{2} \mathrm{~S}$ levels; in addition, the increase in sputum cytokines during exacerbation was either negligible or small.

The role of $\mathrm{H}_{2} \mathrm{~S}$ in the lungs is currently unclear. $\mathrm{H}_{2} \mathrm{~S}$ possesses anti-inflammatory and antioxidant effects in the lungs. In vitro, $\mathrm{H}_{2} \mathrm{~S}$ can suppress airway smooth muscle proliferation and IL-8 release, ${ }^{12}$ and induce vascular smooth muscle relaxation. ${ }^{28}$ In in vivo studies, aggravated airway hyperresponsiveness and increased airway inflammation occurred not only in mouse models of asthma with deficiency of $\mathrm{H}_{2} \mathrm{~S}$-producing enzymes ${ }^{29}$ but also in rat models of cigarette-induced inflammation when CSE was blocked. ${ }^{16}$ Therefore, $\mathrm{H}_{2} \mathrm{~S}$ may have a protective role in COPD. However, other studies have revealed that $\mathrm{H}_{2} \mathrm{~S}$ has a proinflammatory role in regulating the severity of LPS-induced sepsis, ${ }^{30}$ acute pancreatitis ${ }^{31}$ and burn injury. ${ }^{32}$ Inhibition of $\mathrm{H}_{2} \mathrm{~S}$ in animal models was protective of organ injury in endotoxaemia ${ }^{30}$ and so systemic production of $\mathrm{H}_{2} \mathrm{~S}$ might be downregulated during an exacerbation. 
Endogenous $\mathrm{H}_{2} \mathrm{~S}$ synthesis occurs through the action of several enzymes including CSE and CBS. ${ }^{14}$ In airway smooth muscle cells, CBS is the more important enzyme in generating $\mathrm{H}_{2} \mathrm{~S}^{12}$ We have preliminary data indicating that in airway smooth muscle cells from patients with COPD, there is an increase in expression of CBS. An increase in CBS may underlie the increase in $\mathrm{H}_{2} \mathrm{~S}$ found in sputum and serum of COPD subjects. The increase in serum $\mathrm{H}_{2} \mathrm{~S}$ we found in COPD subjects is in agreement with a previous study, ${ }^{19}$ as is our finding of a reduction in serum $\mathrm{H}_{2} \mathrm{~S}$ during exacerbation. The mechanisms by which $\mathrm{H}_{2} \mathrm{~S}$ levels are decreased in serum and increased in sputum are unclear. In addition to increased expression of $\mathrm{H}_{2} \mathrm{~S}$-generating enzymes such as CBS, there could be an increase in inflammatory cells in the lungs during an exacerbation together with an increased bacterial load that could add to the increased production of $\mathrm{H}_{2} \mathrm{~S}$. However, in serum, the reduction in $\mathrm{H}_{2} \mathrm{~S}$ levels may be a reflection of increased sequestration of $\mathrm{H}_{2} \mathrm{~S}$ from the circulation into the lungs.

In our study, the higher the levels of sputum and serum $\mathrm{H}_{2} \mathrm{~S}$, the greater were the degree of airflow obstruction and of neutrophilic inflammation. These results are similar to those found in patients with asthma where the levels of sputum and serum $\mathrm{H}_{2} \mathrm{~S}$ correlated with the degree of airflow limitation and the level of sputum neutrophilia. ${ }^{20}$ In addition, in COPD, the 6MWT distance, which could be influenced by physical activity, and quality-of-life scores among many other determinants ${ }^{33} 34$ also correlated with sputum and serum levels of $\mathrm{H}_{2} \mathrm{~S}$ indicating the potential value of measuring this diffusible marker.

Importantly, these levels may also indicate the risk of an exacerbation. A most significant observation is the decrease in the systemic levels of $\mathrm{H}_{2} \mathrm{~S}$ and an increase in the lung levels of $\mathrm{H}_{2} \mathrm{~S}$ during exacerbations that make this ratio a unique biomarker of a warning system for exacerbations.

We have used a sulfide-ion selective electrode to assay $\mathrm{H}_{2} \mathrm{~S}$ that usually provides levels in the $\mu \mathrm{M}$ range, while other techniques have detected lower levels. ${ }^{27}$ We have added a sulfide-antioxidant buffer to our samples prior to storage and subsequent assay in order to prevent the oxidation of sulfur compounds and avoid the volatilisation of $\mathrm{H}_{2} \mathrm{~S} .{ }^{20}$ Thus, these levels represent the total sulfide pool (rather than solely as $\mathrm{H}_{2} \mathrm{~S}$ ) derived by hydroxyl replacement on cysteine residues in the blood and sputum protein pool. We performed a spiking experiment with different concentrations of $\mathrm{H}_{2} \mathrm{~S}$ added to serum samples and found a tight correlation between the measured and predicted $\mathrm{H}_{2} \mathrm{~S}$ levels. ${ }^{20}$ In terms of short-term reproducibility, serum $\mathrm{H}_{2} \mathrm{~S}$ levels from nine healthy volunteers taken twice over a week period had a mean coefficient of variation of $6.34 \% .^{20}$ However, the short-term and long-term reproducibility of sputum $\mathrm{H}_{2} \mathrm{~S}$ measurements in healthy or COPD subjects is not known.

Other than the inflammatory milieu, other factors may influence the levels of $\mathrm{H}_{2} \mathrm{~S}$. First, the effect of COPD medications, particularly anticholinergic, $\beta$-adrenergic agonists and inhaled or oral corticosteroids on the production of $\mathrm{H}_{2} \mathrm{~S}$, is not known. Corticosteroids may inhibit $\mathrm{H}_{2} \mathrm{~S}$ production in macrophages partly through the inhibition of the $\mathrm{H}_{2} \mathrm{~S}$-producing enzyme, CSE. $^{36} 37$ However, there was no difference in $\mathrm{H}_{2} \mathrm{~S}$ levels between subjects taking and not taking inhaled corticosteroids (data not shown). Fluticasone propionate inhalation had no effect on the levels of sputum $\mathrm{H}_{2} \mathrm{~S}$ in patients with COPD. ${ }^{38}$ Second, bacteria in the upper and lower airways may contribute to $\mathrm{H}_{2} \mathrm{~S}$ production, particularly that the lower airways contain bacteria with an altered bacteriome in COPD. ${ }^{39}$ In addition, $\mathrm{H}_{2} \mathrm{~S}$ produced by bacteria may sustain bacterial growth and suppress their sensitivity to antibiotics. ${ }^{40}$ In our exacerbating patients where conventional sputum cultures were positive for bacteria, the sputum-to-serum ratios were significantly lower than those with negative bacterial cultures, thus indicating the contribution of lower airway bacterial infections to $\mathrm{H}_{2} \mathrm{~S}$ levels.

In summary, concomitant measurements of $\mathrm{H}_{2} \mathrm{~S}$ in sputum and in serum may provide a novel biomarker of COPD. $\mathrm{H}_{2} \mathrm{~S}$ levels may be valuable as a marker of neutrophilic inflammation, chronic airflow obstruction, physical activity and of an acute exacerbation. The clinical utility and validity of measuring the sputum-to-serum ratios of $\mathrm{H}_{2} \mathrm{~S}$ will need to be tested in larger COPD cohorts.

Contributors Conception and design: KFC and JS; analysis and interpretation: KFC and JS; execution and recruitment: JS, DG, PM, CR, RS, AJM and PKB; drafting the manuscript for important intellectual content: KFC, JS and AJM.

Funding NIHR Biomedical Research Unit.

Competing interests This project was supported by NIHR Respiratory Biomedical Research Unit at the Royal Brompton NHS Foundation Trust and Imperial College London. JS was supported by a grant from the Fukushima Medical University, Fukushima, Japan. KFC is a senior investigator of NIHR.

\section{Patient consent Obtained.}

Ethics approval Ethics Committee of Royal Brompton \& Harefield NHS Trust/ National Heart \& Lung Institute and the Ethics Committee of Royal Free Hospital.

Provenance and peer review Not commissioned; externally peer reviewed.

\section{REFERENCES}

1 Murray CJ, Lopez AD. Alternative projections of mortality and disability by cause 1990-2020: Global Burden of Disease Study. Lancet 1997;349:1498-504.

2 Chung KF, Adcock IM. Multifaceted mechanisms in COPD: inflammation, immunity, and tissue repair and destruction. Eur Respir J 2008;31:1334-56.

3 Donaldson GC, Hurst JR, Smith CJ, et al. Increased risk of myocardial infarction and stroke following exacerbation of COPD. Chest 2010;137:1091-7.

4 Donaldson GC, Seemungal TA, Bhowmik A, et al. Relationship between exacerbation frequency and lung function decline in chronic obstructive pulmonary disease. Thorax 2002;57:847-52.

5 Wedzicha JA, Seemungal TA, MacCallum PK, et al. Acute exacerbations of chronic obstructive pulmonary disease are accompanied by elevations of plasma fibrinogen and serum IL-6 levels. Thromb Haemost 2000;84:210-15.

6 Hurst JR, Donaldson GC, Perera WR, et al. Use of plasma biomarkers at exacerbation of chronic obstructive pulmonary disease. Am J Respir Crit Care Med 2006;174:867-74.

7 Hurst JR, Perera WR, Wilkinson TM, et al. Systemic and upper and lower airway inflammation at exacerbation of chronic obstructive pulmonary disease. Am J Respir Crit Care Med 2006;173:71-8.

8 Hurst JR, Perera WR, Wilkinson TM, et al. Exacerbation of chronic obstructive pulmonary disease: pan-airway and systemic inflammatory indices. Proc Am Thorac Soc 2006:3:481-2.

9 Divo $\mathrm{M}$, Cote $\mathrm{C}$, de Torres JP, et al. Comorbidities and risk of mortality in patients with chronic obstructive pulmonary disease. Am J Respir Crit Care Med 2012;186:155-61.

10 Barnes PJ, Celli BR. Systemic manifestations and comorbidities of COPD. Eur Respir J 2009;33:1165-85.

11 Baskar R, Li L, Moore PK. Hydrogen sulfide-induces DNA damage and changes in apoptotic gene expression in human lung fibroblast cells. FASEB J 2007;21:247-55.

12 Perry MM, Hui CK, Whiteman M, et al. Hydrogen sulfide inhibits proliferation and release of IL-8 from human airway smooth muscle cells. Am J Respir Cell Mol Biol 2011:45:746-52

13 Olson KR, Whitfield NL, Bearden SE, et al. Hypoxic pulmonary vasodilation: a paradigm shift with a hydrogen sulfide mechanism. Am J Physiol Regul Integr Comp Physiol 2010;298:R51-60.

14 Wang R. Physiological implications of hydrogen sulfide: a whiff exploration that blossomed. Physiol Rev 2012;92:791-896.

15 Wang R. Two's company, three's a crowd: can $\mathrm{H} 2 \mathrm{~S}$ be the third endogenous gaseous transmitter? FASEB J 2002;16:1792-8.

16 Chen YH, Wang PP, Wang XM, et al. Involvement of endogenous hydrogen sulfide in cigarette smoke-induced changes in airway responsiveness and inflammation of rat lung. Cytokine 2011;53:334-41.

17 Whiteman M, Armstrong JS, Chu SH, et al. The novel neuromodulator hydrogen sulfide: an endogenous peroxynitrite 'scavenger'? J Neurochem 2004;90:765-8.

18 Wang T, Wang L, Zaidi SR, et al. Hydrogen sulfide attenuates particulate matter-induced human lung endothelial barrier disruption via combined reactive oxygen species scavenging and Akt activation. Am J Respir Cell Mol Biol 2012:47:491-6 
19 Chen YH, Yao WZ, Geng B, et al. Endogenous hydrogen sulfide in patients with COPD. Chest 2005;128:3205-11.

20 Saito J, Zhang Q, Hui C, et al. Sputum hydrogen sulfide as a novel biomarker of obstructive neutrophilic asthma. J Allergy Clin Immunol 2013;131:232-4 e231-233.

21 Chung KF. Hydrogen sulfide as a potential biomarker of asthma. Expert Rev Respir Med 2014;8:5-13.

22 Vestbo J, Hurd SS, Agusti AG, et al. Global strategy for the diagnosis, management and prevention of chronic obstructive pulmonary disease: GOLD executive summary. Am J Respir Crit Care Med 2013;187:347-65.

23 Mackay AJ, Donaldson GC, Patel AR, et al. Usefulness of the chronic obstructive pulmonary disease assessment test to evaluate severity of COPD exacerbations. Am J Respir Crit Care Med 2012;185:1218-24.

24 Bestall JC, Paul EA, Garrod R, et al. Usefulness of the Medical Research Council (MRC) dyspnoea scale as a measure of disability in patients with chronic obstructive pulmonary disease. Thorax 1999;54:581-6.

25 Jones PW, Quirk FH, Baveystock CM, et al. A self-complete measure of health status for chronic airflow limitation. The St. George's Respiratory Questionnaire. Am Rev Respir Dis 1992;145:1321-7.

26 Pizzichini E, Pizzichini MM, Efthimiadis A, et al. Indices of airway inflammation in induced sputum: reproducibility and validity of cell and fluid-phase measurements. Am J Respir Crit Care Med 1996:54:308-17.

27 Chen YH, Yao WZ, Gao JZ, et al. Serum hydrogen sulfide as a novel marker predicting bacterial involvement in patients with community-acquired lower respiratory tract infections. Respirology 2009;14:746-52.

28 Wang R. Signaling pathways for the vascular effects of hydrogen sulfide. Curr Opin Nephrol Hypertens 2011;20:107-12.

29 Zhang G, Wang P, Yang G, et al. The inhibitory role of hydrogen sulfide in airway hyperresponsiveness and inflammation in a mouse model of asthma. Am J Pathol 2013;182:1188-95.
30 Collin M, Anuar FB, Murch 0 , et al. Inhibition of endogenous hydrogen sulfide formation reduces the organ injury caused by endotoxemia. Br J Pharmacol 2005; 146:498-505.

31 Bhatia M, Wong FL, Fu D, et al. Role of hydrogen sulfide in acute pancreatitis and associated lung injury. FASEB J 2005;19:623-5.

32 Zhang J, Sio SW, Moochhala S, et al. Role of hydrogen sulfide in severe burn injury-induced inflammation in mice. Mol Med 2010;16:417-24.

33 Gimeno-Santos E, Frei A, Steurer-Stey C, et al. Determinants and outcomes of physical activity in patients with COPD: a systematic review. Thorax 2014:69:731-9.

34 Pitta F, Troosters T, Spruit MA, et al. Characteristics of physical activities in daily life in chronic obstructive pulmonary disease. Am J Respir Crit Care Med 2005;171:972-7.

35 Whitfield NL, Kreimier EL, Verdial FC, et al. Reappraisal of H2S/sulfide concentration in vertebrate blood and its potential significance in ischemic preconditioning and vascular signaling. Am J Physiol Regul Integr Comp Physiol 2008;294:R1930-7.

36 Zhu XY, Liu SJ, Liu YJ, et al. Glucocorticoids suppress cystathionine gamma-lyase expression and $\mathrm{H} 2 \mathrm{~S}$ production in lipopolysaccharide-treated macrophages. Cell $\mathrm{Mol}$ Life Sci 2010:67:1119-32.

37 Li L, Whiteman M, Moore PK. Dexamethasone inhibits lipopolysaccharide-induced hydrogen sulphide biosynthesis in intact cells and in an animal model of endotoxic shock. J Cell Mol Med 2009;13:2684-92.

38 Kirkham PA, Whiteman M, Winyard PG, et al. Impact of theophylline/corticosteroid combination therapy on sputum hydrogen sulfide levels in patients with COPD. Eur Respir J 2014;43:1504-6.

39 Hilty M, Burke C, Pedro H, et al. Disordered microbial communities in asthmatic airways. PloS ONE 2010;5:e8578.

40 Shatalin K, Shatalina E, Mironov A, et al. H2S: a universal defense against antibiotics in bacteria. Science 2011;334:986-90. 